\title{
Transformative Moments: An Interview with Janette Turner Hospital
}

\author{
Belinda McKay
}

Janette Turner Hospital is the author of eight novels, four collections of short stories, a novella published only in French, and a crime thriller under the pseudonym Alex Juniper. Her work has been published in 20 countries, and in 12 languages other than English. She is the recipient of a number of overseas literary awards, and both Griffith University (in 1996) and the University of Queensland (in 2003) have conferred honorary doctorates upon her. In 2003 she won the Queensland Premier's Literary Award for Best Fiction Book for her most recent novel, Due Preparations for the Plague, and the Patrick White Award for Lifetime Literary Achievement.

Born in Melbourne in 1942. Turner Hospital moved to Brisbane when she was seven and the experience of growing up in Queensland permeates her literary mindscapes. She attended Mitchelton High School and the University of Queensland, graduating with a Bachelor of Arts in 1965. After teaching in Queensland high schools for several years, she moved with her husband to north America, where she has been based for over 30 years. Janette Turner Hospital is currently Carolina Distinguished Professor and Distinguished Writer-in-Residence at the University of South Carolina. Ironically, Queensland and South Carolina are officially twinned states.

I interviewed Janette Turner Hospital at her lakeside home outside Columbia, South Carolina, in November 2003.

Belinda McKay: Janette, you've lived in North America for more than 30 years, but Queensland - where you grew up - still has an important place in the imaginative world of your writing.

Janette Turner Hospital: Oh, yes, it's huge. It's the mythic space I live in, I suppose, but it's not as though I ever lost touch with Queensland. I keep reading these things in Australia that say, you know, she hasn't been in Australia for 30 years, but the thing is I'm back every year, and always have been, and sometimes for quite extended periods of time - up to three months at a stretch - so I have 
never dissociated myself from Queensland, either physically or emotionally. I have multiple connections that have always been living connections, live connections.

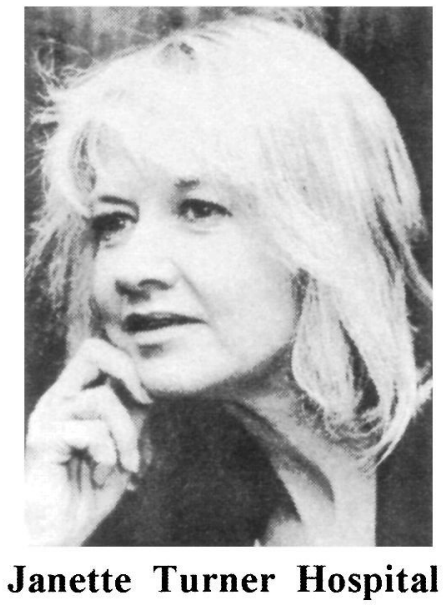

$B M$ : What do you mean when you say that Queensland is the mythic space you live in?

JTH: I mean it in the physical sense: the rainforest and the coast, and recently the outback, which was not part of my childhood but which was a relatively late discovery. 1990 was the first time I'd ever gone beyond the end of the paved road, beyond Quilpie, but I keep being pulled back there. The rainforest, the coast and the outback always seem to me time eternal: they're unchanging in and of themselves. Human society makes changes to them, usually dreadful ones like logging the rainforest, but where the rainforest still is you have this sense of the insignificance of the time of humanity on the globe, and that's what I mean by mythic space. It's the place, it's the sense I go back to every year, and literally physically reconnect with, and that really feels like a psychic necessity to me. If there gets to be a time when I'm too old and decrepit to do this every year - and I've got to admit I find the plane flights harder and harder to take - then that's probably the point that I'll just go back to die, I suspect. I don't know. It'll be a hard choice because our children and grandchildren are over here and that's obviously as intense a pull as what I think of as the atavistic pull of Queensland on me, but it is one of the reasons why I am much more at ease in South Carolina. It feels like a displaced homecoming because it feels much more climatically and physically natural to me to be living in this kind of space, especially the Carolina coast even more than Columbia.

$B M$ : In relation to that atavistic pull, it seems that for you there's a Garden of Eden dimension to Queensland, with possibilities for both good and evil. Some evil things are set in rainforests in your stories and novels ...

$J T H$ : And certainly in the outback. I don't consciously think of it that way but I'm sure there is, given the kind of fundamentalist religious background that I had in my childhood. I'm sure it's just simply there - the Garden of Eden mythology. 
overlaid or coeval with the sense of Queensland as eternal space, primitive space, primeval space, where indeed good and evil can equally be enacted.

EM: Is that another similarity with South Carolina?

JTH: Yes. there are many similarities besides the climatic and the vegetative ones between Queensland and South Carolina. I think for that reason I've always felt a real affinity with Southern literature, in its reverberations with Faulkner, when I first discovered him. There are enormous similarities in the feudal politics for a start. Joh Bjelke-Petersen has his parallel in Strom Thurmond, who died in 2003 at the age of 100. the longest serving Senator in United States history, alreadyhaving become the Senator for South Carolina when I was in high school in Queensland! It's absolutely extraordinary. Both Joh Bjelke-Petersen and Strom Thurmond had arch-conservative policies, so there's that similarity, and there's a pretty ugly history of race relations in both states.

What I hadn't anticipated, and what is very different here in South Carolina, is the effect of the Civil War. There's never been a civil war in Australia, and one of the things I discovered coming to South Carolina is that of course it's not called the Civil War here - that's a Northern term for it. It's called the War of Secession or the War Between the States or the War of Northern Aggression. I've had to give myself a crash course in Civil War history since I've been here. I've had to buy a dictionary of the Civil War, because it comes up so frequently. I had been told by Northerners that it would be as though the Civil War ended ten years ago, and I'd assumed that was Northern, Yankee, poetic exaggeration, but it isn't. It just comes up constantly. It's like a raw festering wound, whether you're black or white in South Carolina. This was the first state to secede; this was the heart of the Confederacy; this was the one state that was still flying the Confederate flag from the State House dome when I got here a mere four and a half years ago!

My first civic act was to join a march of 50 thousand people from Zion American Baptist Church, which is a black church, on the State House. And a lot of my colleagues from the university and all of the students marched too. but we were about the only white marchers. That really shook me, that only about 5 per cent of the march was white, and that was at a time when the polls were showing that something like 70 per cent of white South Carolinians thought it was time for the flag to come down, and that it had become a national embarrassment to them, but it was still too costly and risky a thing to be seen actually joining a black march over that issue, and this was four years ago. The flag has come down. It is on a flag post in front of the State House now, just behind the Confederate Soldier monument.

That is a dimension to life in South Carolina that has no comparable feeling in Queensland. Certainly in Queensland there's lots of distrust of Sydney. Melbourne and Canberra, especially in rural Queensland. I taught in Far North Queensland and I have spent a fair bit of time in outback Queensland and there's radical distrust of the 'toy boys' — that's the usual expression — in Sydney, Melbourne and Canberra. But there's nothing to compare to the way Southerners think of Yankees and Northerners, and that continues to be of endless fascination to me. 
Cars with Yankee plates - and Yankee means anywhere north of the MasonDixon Line - can have their tyres slashed, can have score marks along the paintwork of their cars. We were advised to change the plates on the car very promptly even though they were Canadian. Anything Northern is suspect here, and there's just no equivalent to that in Australia.

$B M$ : No. but there's a view from the southern states of Queensland as the 'Deep Worth's

JTH: Yes, there is, and one thing that I as a Queenslander understand about Southerners is that Northerners look down on Southerners as backward and hillbilly. Southerners become very self-conscious about their accents if they go north. That attitude to Queensland certainly exists in Sydney and Melbourne and just makes me furious. To me it feels like a completely unwarranted assumption of intellectual and cultural superiority to Queenslanders. I find myself, as a Queenslander, feeling angry when I'm in Melbourne - a place that I very much dislike, I have to say. I generally try to disguise, or shade over, the fact that I was bom there, which I consider an unfortunate accident. I was only seven when I moved to Queensland and I think of myself quite passionately as a Queenslander. I really dislike Melbourne. I find it a place of unwarranted smugness in university circles and in literary circles.

$B M$ : Nonetheless, there is a kind of rawness both here in South Carolina and in Queensland. One of the things that emerges in your stories is an awareness of the racial dimension in Queensland. It appeared early in your work ...

JTH: Well I discovered it early in my life, relatively early. I was 20 when I was sent to North Queensland and lived in Mossman and there was an Aboriginal reserve 3 miles outside the town. I was teaching at the 'High Top'. The town wasn't big enough to have a High School so it had a 'High Top', which was two years tacked on to the primary school. We actually had a couple of classrooms in the primary school buildings, and I was the arts teacher for the 'High Top'. I taught English, French, History and Geography, and I had only one Aboriginal student. Once they reached 14, which was school leaving age then, the Aboriginal kids left. The primary school, of course, had all the Aboriginal kids. They all walked in barefoot. Of course, plenty of white kids walked barefoot to school in those days too, and maybe still do in North Queensland. I had a student called Hazel - whom I actually named in the first short story I ever wrote, 'She Gave Me Hyacinths' - in North Queensland. She was one of six or seven children, and they took turns to share the lunch that they brought in. I used to walk out to the Gorge on the weekends and talk to Hazel and I was just appalled at the poverty and the way Aboriginal people were treated. Adults had to go and ask the police chief for their pocket money to buy enough food for their kids. The police chief' s daughter was in the same class as Hazel - that's the way it is in small Queensland towns - but her parents were treated like children. I became very viscerally aware of this at the age of 20 . 
BM: In another of your stories, 'The Second Coming of Come By Chance', a white woman is raped by the police as punishment for socialising with Aboriginal people.

JTH: Well, I also became aware of the nature of the Queensland police. Now there' $\mathrm{d}$ be plenty in common with the South Carolina police force, at least until a few years back. Recently, when I got to know Sam Watson - I'm trying to remember exactly when I met Sam, I think about 1990 — he told me that a decade previously any Aboriginal person arrested by the Queensland police would be beaten up with impunity 90 per cent of the time, and that they'd reduced that to about 60 per cent of the time. His goal was to make it that it couldn't be done with impunity. So I did become aware early on of the way the police regarded the Aboriginal community. And of course people who join the police force - I got to be aware of this in Boston too. where I made a point to get to know the police because I'd first met them on demonstrations - people who sign up for the police force are themselves people without too many career options. They're often angry people, and their anger is expressed in violence, and of course it gets expressed in violence at the targets least likely to get them into trouble. I come from a working-class background myself, and in fact I have a cousin who is a member of the Queensland Police Force, so I'm always interested in the complexities of levels of oppression, levels of expressing anger within society. No one is ever straight out villainous. There are complex levels, and I'm always trying to explore how and why and at what points those might change.

$B M$ : Well, there's certainly violence in your novels. In your Queensland settings, there's violence against Indigenous people and there's also violence against women. In Borderline, Hester and Felicity are raped at school by a pack of very young boys. Do you also see violence against women as a particular problem in places like Queensland and South Carolina, for historical reasons?

$J T H$ : I'm wary of making general statements like this, but I do have experience with rural and agrarian society in Queensland and in Ontario in Canada and now in South Carolina. It seems to me - on the basis of my not entirely limited experience, but still too limited to be making universal statements - to be a product of the disenfranchisement which often goes with rural poverty and a distribution of labour where men do the heavy physical stuff and women look after the children and keep house. The weariness and the violence come out in domestic friction. South Carolina, for example, is number one of the 50 states for domestic violence and domestic murders per head of population, and I don't know what the statistics are in Australia, but it wouldn't at all surprise me if Queensland or the Northern Territory were number one there. I do think that rural poverty seems to have a lot to do with it. But I don't want to make that a universal statement as I realise I just don't know enough. I also think that, in Australia, hostility to women does go back to convict beginnings; it's left deep grooves in the psyche, and it's very much still part of the whole Australian ethos, I think. 
I never got a driver's licence in Australia because I grew up in a climate where every male I knew - my father, my brothers - made jokes about women drivers and women who went for driving tests got teasingly abused by the police with whom they were taking the test. I grew up with the attitude that women were incompetent at anything outside the home, and I must say it's been a lifetime's effort to shed myself of that internalised idea. I tend to shed myself of it the way Australian women have had to - alternately being very aggressively determined to show that you're not second to anybody, and having periods of panic and retreat where you feel you're no good at all and have to do a lot of talking to yourself. It's very deeply internalised in me, and it continues to be a fair bit of work dealing with it in my sixties. I'm sure it would have been exacerbated in my case growing up in a fundamentalist community where a woman's place was biblically ordained. Actually, I take that back because we got such mixed signals. In other ways I would say we had a stronger sense about our identity as equal in the sight of God except that you couldn't become elders in the church, etc. I actually got very confusing, mixed feedback on that. Some of it probably gave me strength, and other parts of it taught me not to speak out but to learn to exercise power quietly and unobtrusively in subversive ways.

$B M$ : In a lot of your work - and I'm thinking particularly of the story 'Morgan Morgan' - the transformative power of the imagination is quite akin to the transformative power of the spirit. I wonder if that's something that you've taken from your childhood. That particular story is almost Blakean, I think.

JTH: Well I just adored all four of my grandparents, and Grandpa Morgan was a larger than life figure who had had a dramatic conversion which was part of familylegend. But there was a pagan, Celtic, Welsh core to Grandpa. He was a great storyteller, a mythic storyteller, and I felt like he connected me to the whole cycle of Celtic legend. I'm sure it has a lot to do with why medieval literature appeals to me. I just don't think Grandpa's pagan side ever got quite tamped down. It always seemed to be there and quite thrilling to me, because periodically although he was a bom-again Christian to the core, and that's the only way I knew him - he would say things that would shock everyone, and you had to remember that that belonged to the old world [laughs].

Grandpa Turner was the opposite. He was very English and classically trained and told me stories of Greek and Roman myths. He was an intellectual who came to the colonies to search for his father who'd absconded. That's the other story about my other grandfather, 'The Bloody Past, The Wandering Future', where my great-grandfather absconded, and left a wife and infant son in England. So, my imagination was fired by these wonderful grandparents, who told wonderful stories. Grandma Morgan had stowed away on a ship to Western Australia and worked on the goldfields. So I really felt connected to all this nineteenth century Australian legend.

$B M$ : Fundamentalist upbringings are often depicted as very dour, yet it seems clear to me. from reading your work, that there was a kind of richness which was not without its problems but offered a great wealth of ways of transforming oneself. 
JTH: When you grow up in a fundamentalist world you actually grow up in a mythic narrative space because everything in the Old Testament has immediate relevance and you read it at the dinner table, so in a way you grow up in timeless space. You grow up with a 'God's eye' view of time because you always know that the second coming could be tomorrow or next week. Every Sunday you are told that you are living in the end time. There's always this feeling that at any moment God is going to call mankind to account and, oddly enough, even though all sorts of things that were thought to tempt the imagination were ruled out of bounds, we lived in pretty free narrative and imaginative space all the time. The Bible is a very rich narrative and poetic heritage.

There was a period in my high school and college years when I chafed enormously against the intellectual restrictions, which of course were easy to subvert privately by just going off to the library and reading. I chafed against the social restrictions - I was 20 before I saw a movie - and I felt angry about them, but I do realise in retrospect what Pentecostalism does for marginalised people. I remember, for example, that the people who came to our church were really the marginalised people of Brisbane, such as the cook from one of Brisbane's ritzy private schools - I think it was Somerville House. Pentecostalism looks dour from the outside because you didn't go to movies, you didn't go to dances, but these were people who most of the time would not have had the discretionary income to go to those things anyway, and it was a very warm, loving community. Everybody hugged everybody else when they arrived, and you were at church all day Sunday. There were 'pot luck' lunches, where everyone brought something and shared the meal. It gave tremendous mutual support to people who got it nowhere else. So in some ways it was very empowering for people.

Pentecostalism gave me lots of mixed feedback, but it certainly it gave me great training in rhetoric because the pastors all came out from Wales and they really were rhetoricians. I was mesmerised by the power of the Word. They were hellfire and brimstone preachers but they really had a sense of art, and I feel the same when I hear black preachers in South Carolina. When I joined that march on the State House, one after one all these black preachers would speak to the crowd, and the crowd would chant and sway, and we began to sing 'The flag must come down - todaaaay!' to the tune of 'We Will Overcome.' It was incredibly stirring and I found tears in my eyes, but it reminded me actually of childhood Revival meetings. Also. I'm very aware that the black church in the South is the major form of empowerment - political empowerment - and all politicians, especially the white Democrats, do the rounds of the black churches here. So, it always has irritated me actually the glib ways in which white academics and intellectuals within Australia, knowing zilch about it, dismiss fundamentalism as a totally oppressive system. It certainly can easily become that, but the reason Pentecostalism is growing hugely in the world, especially in South America and in Africa, and the reason the black church is huge here, is because it is a form of empowerment to marginalised people initially, and I don't feel that anybody in intellectual and academic circles in Australia has any inkling of that. 
BM: Your fundamentalist background didn't stop you from being educated at the University of Queensland and becoming a teacher. How did that come about?

JTH: Actually, again that probably was because of the legacy of Grandpa Turner and of my great-grandfather Turner, who'd been a barrister and had been presented with the keys of the city of London. I've never known the story of why my greatgrandfather just disappeared from Eastbourne in England. I assume embezzlement, or a woman, or some scandal that he was fleeing. My grandfather eventually found out that his father had turned up in Brisbane and he journeyed to Australia to find him. He did find his father, but his father was horrified to be found. This broke my grandfather's heart. My grandfather always cherished learning and had a grammar school education and became a headmaster in country schools in Victoria, but the Depression and the war meant that Dad didn't finish high school. But he had a reverence for education and was determined that his children would go to university, which was a huge sacrifice for my parents. Although we did win scholarships, it still was a big sacrifice because it was the kind of family that urgently needed kids to contribute to the family income as soon as possible. I remember my father defending his right to educate me to the rest of the congregation who thought that this was a really dreadful thing, and that if young people went to university they lost their faith. It was not just a dreadful thing but a very pointless thing for a girl to go to university and I can remember that being a point of contention.

$B M$ : Was it a problem for your father that, in a way, they turned out to be right?

JTH: It has always made him suspect in that congregation, and yes I have always felt slightly guilty that they turned out to be right of course. I encouraged Dad to do a BA when he was in his sixties then an MA. He was dead scared but he also terrifically wanted to do it. I know it was problematic for him as I had several old friends who actually taught him. He had a very rigid mind-set. He was an adult convert to Pentecostalism in the war years when he was scared and he went to a little gospel hall and felt embraced by an empowering force.

One of the things that interests me is how quickly things that begin as liberating and empowering turn into their own systems of oppression and rigidity. For years, I toyed with doing a scholarly book on this, a sort of comparative study of fundamentalisms, and I was going to do everything from Christian fundamentalism to Islamic fundamentalism to Hasidic fundamentalism to Marxist fundamentalism to feminist fundamentalism, because certainly feminist fundamentalism got to a point where it seemed to me astonishingly similar to what I experienced when I began to try to find leeway within Pentecostalism. Especially in Australia, academic feminism became terribly narrow and rigid and you could be outcast for using the wrong vocabulary, which is exactly what happens within Pentecostalism. I planned to make comparative studies to trace the movement from liberation and empowerment to - all too rapidly — oppressive rigidity. But then I realised that I would just much rather write stories and novels, on little aspects of it in individual people rather than do a scholarly study. I hope someone does write that scholarly comparative study some day, but I'm not going to be the one who does it. 
$B M$ : Your interest in fundamentalism certainly works itself out in your novels, especially in the most recent one. Due Preparations for the Plague, which deals with the hijacking of a plane by terrorists and the deep trauma and grief of the survivors. You have an abiding interest in how individuals and groups of individuals move forward in the face of terrifying events. Your father's conversion experience during World War II was one response ...

JTH: And my grandfather Morgan's before that. He had a dramatic conversion on the West Australian goldfields. Actually I am going to fall back on the vocabulary of childhood because I have observed, and I believe in. these redemptive moments. Transformative moments might be a more neutral theological term to describe them. Those moments interest me greatly and that's what I write about. I'm fascinated that those moments can come about. They come about through interactions between two human beings and what fascinates me is that quite flawed people, even people whose accumulated impact is not good - you know, they're 'bad people' - there are moments when two human beings can touch and transform one another's lives. I've had it happen to me at times, at certain critical points in my life where just one person's act of really going out of the way to be encouraging or helpful, or of astonishing me by their unexpected belief in me, can be absolutely transformative. This is what happens, I guess, in conversion experiences. You know, my father lonely in Melbourne and in the Air Force, with the war raging, walks into a little gospel church and suddenly feels that his life could be transformed and that he could feel it all had meaning. That no longer has currency for me in a theological sense. But I do know that lives can be transformed in a moment of time by human encounters.

$B M$ : Is that the role of the Word?

JTH: Well, yes. Books can do it for people and words can do it. Actually I'll tell you an interesting story that altered my pedagogical method when I was teaching in Canada. I taught in a maximum security prison and then, only a few years after that. I taught a high school class of really reprobate students. It was when I was expanding my career as a substitute teacher filling in for bum-outs and people with back injuries. This class was called Level 3 , and they were basically kids who once would never have gone to high school and didn't want to be there but had to be there until they reached legal age. It was a small class of ten, and they were really wild. It was like being in a room with wild animals. It was pretty scary. I mean, they threw chairs around the room - really wild. They were hyper-conscious of being put in this class. They asked me and got permission to tape brown paper over the doors, because all the classroom doors at that time were glass, and they didn't like to be seen belonging to this class. And then I found out that every person in that class had a father or a brother who was either an inmate or a guard. There were five prisons in Kingston, five federal penitentiaries, and one of the kids had a father who was a guard and a brother who was an inmate.

So with this class I decided to try a book called Go-Boy] by Roger Caron. who had the record for the most jail-breaks in Canada. He was in a maximum security prison by the time he was in his late twenties. He'd never actually committed a 
violent crime. He'd first been incarcerated about the age of 16 for breaking and $_{\text {oncum }}$ entering, and although he'd never physically harmed anyone or killed anyone, he kept getting escalated up the system because of his jail-breaks. Since he always made trouble in prison, he was put in what is called in prison terminology in Canada the hole', which was solitary confinement. It was below the level of the walkways that the guards walked along, and was behind bars. The point at which Roger Caron's life changed and he became an educator and wrote his book was when he had to spend Christmas in 'the hole'. The Salvation Army had come and given all the prisoners a little bag of jelly beans as a Christmas present, and a guard walked along early on Christmas morning banging his baton, bang, bang, bang, bang, bang, along the bars of 'the hole', and there was Roger Caron furious but powerless to stop this humiliation and with the jelly beans he spelled out on the floor of his cell 'PIG'. It sent the guard into a tantrum - he was just furious.

This was a transformative moment for Roger Caron. He was virtually illiterate at this point, but he was struck at that moment the way St Paul on the road to Damascus was struck. Roger Caron suddenly realised the potency of a word, and his life was changed. He vowed that he would learn to read and he took advantage of all the prison education opportunities which had hitherto held no interest whatsoever for him. Eventually he served his term and became an adviser to the federal government on education in the prisons. That is the most powerful story I know of the power of the word to transform.

When I used Caron's book with the kids in Level 3, that was a transformative pedagogical experience for them and for me because I had noticed that they were hostile, very hostile, towards books as physical objects. They would rip them up and stomp on them. They expressed hatred towards the books themselves, which was both fascinating and alarming to me. My own kids loved books because we read stories to them from when they were very little, but no one had ever read stories to the kids I was teaching. So I began by simply reading to the class from Roger Caron's book, serialising it from one class to the next. It was right up their alley. Then I ordered a classroom set of the book. These kids were pretty close to illiterate and they were 15 years old, but I had them follow while I read aloud, and then I'd get to these really raunchy bits where Caron would escape and spend a night with his girlfriend or describe what he felt about the guards, and I would say: 'I can't read. I'm too embarrassed to read this next bit. Would you like to do that?' They'd do that with great relish - all the 'fuck' words. And then they began asking could they take the books home, so I had them sign them out. They could only take them home if they brought them back the next day in good condition, and then I began to set exercises based on the text. It was a literacy class really, but it got them excited about that book anyway. It was as if until then books had been a part of the oppressive system that made them feel like failures. Books had simply been part of the system that chained them and finally they found a little gateway into books as their own private pleasure.

I suppose in a way that's what my writing is about, exploring these transformative moments and hoping that they help other people, and from time to time I get letters from people or meet people who tell me that they do. 